\title{
原著
}

血管迷走神経反射が原因と考光られためまいの三症例

$$
\begin{gathered}
\text { 正木 義男 } \cdot \text { 渡辺 道隆・古川 朋靖 } \\
\text { 加納 昭彦 } \cdot 山 \text { 山谷千恵美 }
\end{gathered}
$$

\section{Three Case of Dizziness Due to Vasovagal Reflex}

\author{
Yoshio Masaki, Michitaka Watanabe, Tomoyasu Furukawa, \\ Akihiko Kano, Chiemi Yamatani \\ Department of Otorhinolaryngology, Juntendo University School of Medicine
}

\section{Introduction}

Vasovagal reflex (VVR) is a disease that has received attention in various fields.

Recently, researchers have started to clarify its mechanism. Three patients with symptoms probably due to VVR were treated in this department and the Head up tilt test was used to diagnose dizziness due to VVR.

Patients

The three patients included a 21-year-old female (Case 1), a 26-year-old male (Case 2) and a 61-year-old female (Case 3). All three patients had chief complaints of spontaneous dizziness after standing or sitting for 5 to 30 minutes.

Results

The duration of standing before the onset of positive findings was 9.5 minutes in Case 1 and 11 minutes in Case 2. In Case 3, positive findings were obtained 9.5 minutes after isoproterenol administration.

Discussion

All three patients showed spontaneous dizziness in either the standing or sitting position and the results of the Head up tilt test were positive. Therefore, dizziness seemed to be due to VVR in these patients. The instantaneous decrease in blood volume due to paradoxical activation of the vagus nerve may have induced dizziness, loss of consciousness and faintness. Because of severe patient stress during the Head up tilt test, this examination should be indicated only in those who are strongly suspected of VVR.

Key words: dizziness, vasovagal reflex, autonomic nervous system, Head up tilt test

\section{はじめに}

自律神経の異常によりめまいが起こることは以 前より指摘されており，血管迷走神経反射（Vasovagal reflex, 以下 VVR と略す）と起立性調節障

順天堂大学医学部耳鼻咽喉科学教室
害 (Orthostatic dysregulation, 以下 OD と略す) が代表的疾患である。

VVR は1932年に Lewis ${ }^{1)}$ が報告しているが， その機序が解明されてきたのは近年になってから である。立位または座位では下肢に血液が貯留す るが，不足した循環量を補らために左室の過剩収 


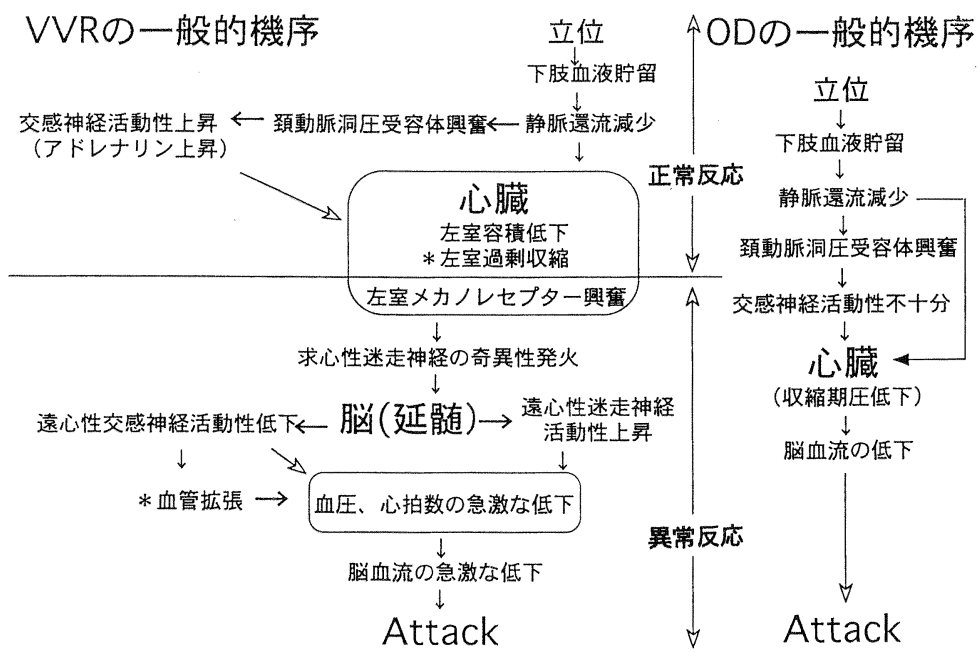

図 1 VVR と OD の一般的機序

*はイソプロテレノールの作用点。

縮が起きた結果，メカノレセプターを介して迷走 神経の奇異性発火が起き，血管拡張による血圧低 下と徐脈により循環量が低下してめまい感, 眼前 暗黒感, 失神発作等が起きると考兄られている (図 1 ) 2) 7)。

VVRの診断にはあまり有効なものがなかった が，近年その診断に Head up tilt（以下 HUT と 略す）試験を活用した報告が多く見られ，様々な 研究施設からその有効性が報告されている2) 8)。 今回 VVR が原因と考光られためまいの三症例を 経験し，その診断に HUT 試験を活用したので報 告する。

\section{方 法}

当院の HUT 試験とプロトコール

15分安静臥位の後, 80度までチルトテーブルを 起立させ 30 分間血圧，心拍数を持続的に測定す る。血圧はトノメトリー法を併用。30分間で血 圧，心拍数の急激な変化がなかった場合，イソプ ロテレノールを点滴静注負荷し, 再度チルトテー ブルを起立させ 10 分間血圧，心拍数を測定する。 血圧, 心拍数の急激な低下を伴い, 失神, めまい を誘発したものを陽性とした（図 2,3 )。

症例

症例 1

21歳, 女性 大学生。

主訴：めまい感。

現病歴: 平成 5 年初旬, 立位で仕事中, 20 分後

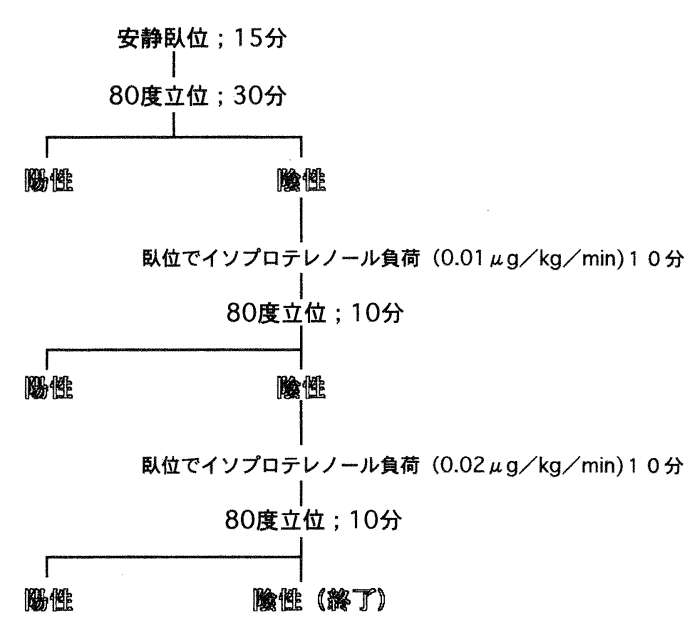

図 2 当院の HUT 試験のプロトユール

に眼前暗黒感を伴う，意識が遠くなるような自発 性のめまい感が出現した。めまい感は数秒間続い た。その後, 立位で同様の症状が頻繁に出現する ようになった。平成 6 年 12 月頃より，座りながら 勉強していると知らないうちに眠り込んでいるこ と頻回にあり，また平成 6 年 5 月にはバスの中で 立っていたところ約 20 分後に失神発作もあった。 近医耳鼻科で治療を受けるが改善しないため紹介 により当科受診した。

既往歴: 平成 4 年 12 月 26 日交通事故。頭部 CT 等では異常なかった。他は特記すべき事項なし。 


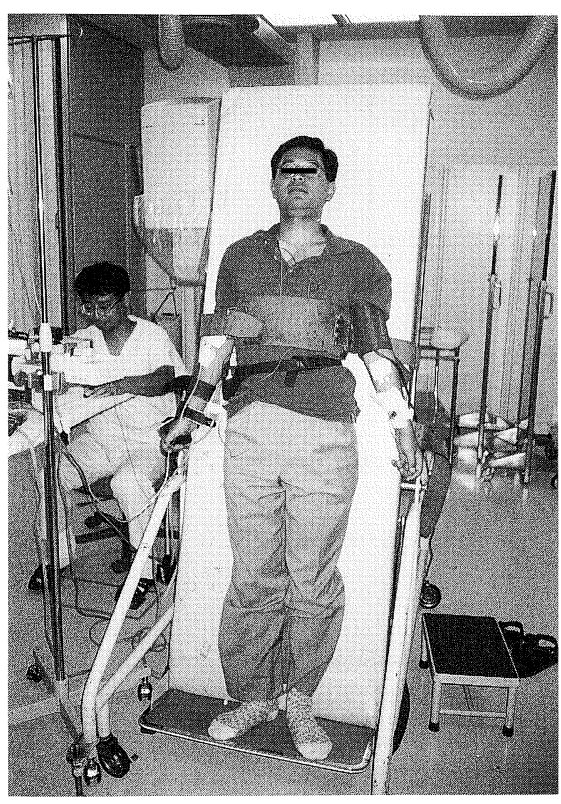

図 3 HUT 試験時の写真 $\left(80^{\circ}\right.$ 立位 $)$

ルート確保し心電図を装着。

右手はトノメトリ一法, 左手はマンシェッ ト式の血圧計を装着。

検查所見 :

耳鼻咽喉科的診察で特記すべき事項なし。

純音聴力検查 右 $5.00 \mathrm{~dB}$

左 $10.0 \mathrm{~dB}$ (4 分法)

平衡機能検査では自発眼振, 注視眼振を認め ず，また頭位，頭位変換検査で眼振を認めず。

神経学的検査で異常を認めず。

偏倚検査, 立ち直り検査で明らかな異常所見な し。

ENG で明らかな眼振, 異常眼球運動を認め ず。

ABR で異常を認めず。

脳波検査で異常を認めず。

心電図で異常を認めず。

血液検查で明らかな異常値なし。

頭部 CT, MRI を含を画像検査で異常を認め ず。

Schellong Test : 陰性

安静時: 心拍数70 血圧 $92 / 70$

起立 1 分後 : 心拍数 87 血圧 $94 / 70$

起立 5 分後 : 心拍数 82 血圧 $100 / 70$
起立 10 分後：心拍数 82 血圧 $100 / 65$ （安静時間 10分, 単位 心拍数 $/ \mathrm{min}$, 血圧 $\mathrm{mmHg}$ )

HUT 試験：陽性（図 4)

立位直後に若干の血圧低下と心拍数の増加を認 めたが，めまい感や眼前暗黒感はなかった。

立位 9 分で意識が遠くなるよらなめまい感が出 現した。

立位 9 分 30 秒で意識消失，血圧低下，4秒間の 心停止（ホルター心電図で】の部分）を伴う徐脈 が出現した。陽性と判断し試験を中止した。

中止 30 秒後飞は心拍数, 血圧共飞安静時と同様 の値に回復した。

治療と経過：この症例については発作直前に急 激な心拍数の増加を認めたことから $\beta$-ブロッ カーを三カ月間投与した。緊張時に軽いめまい感 が起きることもあるよらだが現在大きな発作はな

く，日常生活泟支障は来していない。 症例 2

26歳, 男性 自営業。

主訴：めまい感。

現病歴: 平成 7 年11月中頃, 立位で仕事中, 10 分後に頭を後ろに引かれるよらな自発性のめまい 感が出現した。めまい感は数秒間持続し, 眼前暗 黒感を伴った。また，一週間後立位でマッサージ を受けていたところ立位 10 数分後注失神発作があ り，その後も立位または坐位で一瞬意識がとぎれ るような感覚を伴う数秒間の自発性のめまい感が 頻繁に出現するようになった。このため平成 8 年 1 月 18 日, 当院循環器内科および耳鼻科を受診し た。

既往歴：特記すべき事項なし。

検査所見 :

耳鼻咽喉科的診察で特記すべき事項なし。

純音聴力検查 右 $1.25 \mathrm{~dB}$

$$
\text { 左 } 2.50 \mathrm{~dB} \text { ( } 4 \text { 分法) }
$$

平衡機能検査では自発眼振, 注視眼振を認め ず，また頭位，頭位変換検査で眼振を認めず。

神経学的検査で異常を認めず。

偏倚検査, 立ち直り検査で明らかな異常所見な 乙。

ENG で明らかな眼振, 異常眼球運動を認め ず。

ABR で異常を認めず。

心電図で異常を認めず。 


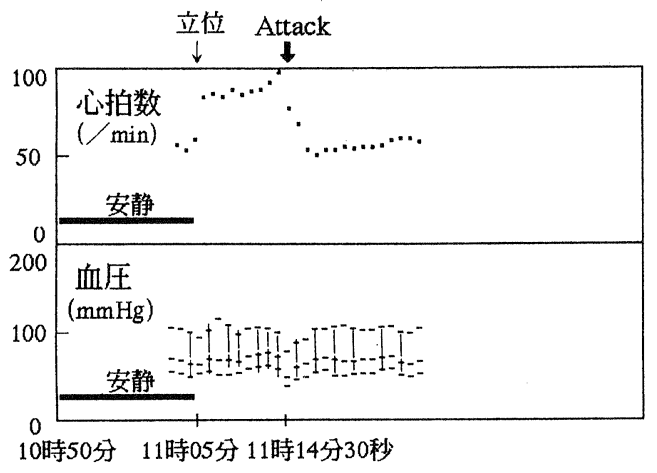

\section{ホルター心電図}

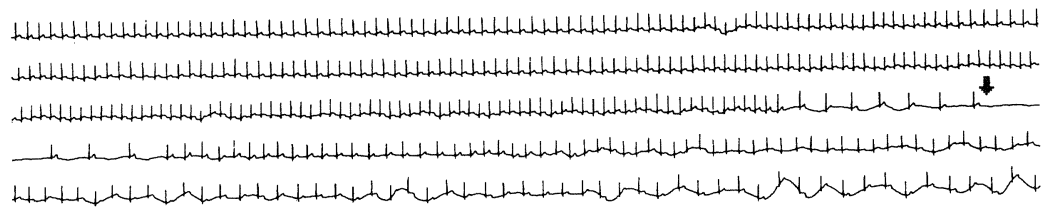

図 4 症例 1 の HUT 試験時の心拍数之血圧

11 時 05 分試験開始。

立位 9 分 30 秒（11時14分30秒）で心拍数，血圧の急激な低下を認める。（ホルター心電図は発作前後の約

3 分間を記載した。】の位置で 4 秒間の心停止を認める。)

血液検査で明らかな異常值なし。

頭部 CTを含む画像検査で異常を認めず。

Schellong Test : 陰性

安静時 : 心拍数 60 血圧 $100 / 60$

起立 1 分後: 心拍数 77 血圧 $98 / 65$

起立 5 分後 : 心拍数 73 血圧 $110 / 60$

起立10分後：心拍数 75 血圧105/65（安静時間

10 分, 単位 心拍数 $/ \mathrm{min}$, 血圧 $\mathrm{mmHg}$ )

HUT 試験：陽性（図 5 ）

立位直後に若干の血圧低下と心拍数の増加を認

めたが，めまい感や眼前暗黒感はなかった。

立位 10 分 30 秒で頭を後ろに引かれるようなめま

い感が出現した。

立位11分で意識消失，血圧低下，10秒間の心停 止（ホルター心電図で】の部分）伴ら徐脈が出現

したため陽性と判断し試験を中止した。

中止 30 秒後には心拍数, 血圧共に安静時々同様 の值に回復した。

治療と経過：この症例については発作直前の心 拍数に大きな変化がなく，血圧のみが急激に低下 したことからジソピラミドを三カ月間投与した。
現在大きな発作はなく経過は良好である。 症例 3

61 歳，女性 主婦。

主訴：めまい感，右耳鳴。

現病歷： 5 年前の昼, 立位で台所仕事をしてい たところ，15分後に右の耳鳴と自発性のめまい感 が出現し転倒した。めまい感は10分程持続し, 眼 前暗黒感と右耳鳴を伴った。その後立位 $10 \sim 30$ 分 後に自発性の数秒間のめまいと右耳鳴が頻繁に出 現するようになった。近医耳鼻科受診し治療を受 けるが改善ないため, 平成 8 年 6 月 7 日当科外来 を受診した。

既往歴：特記すべき事項なし。

検査所見：

耳鼻咽喉科的診察で特記すべき事項なし。

純音聴力検査 右 $18.75 \mathrm{~dB}$

$$
\text { 左 } 21.25 \mathrm{~dB} \text { (4 分法) }
$$

平衡機能検査では自発眼振, 注視眼振を認め ず，また頭位，頭位変換検査で眼振を認めず。

神経学的検査で異常を認めず。

偏倚検査，立ち直り検查で明らかな異常所見な 


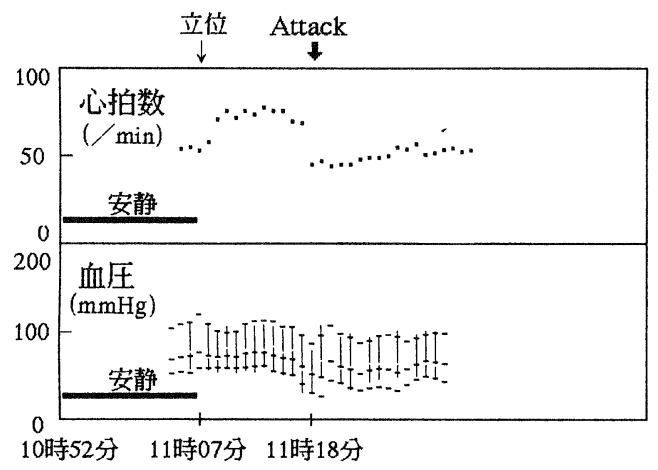

\section{ホルター心電図}

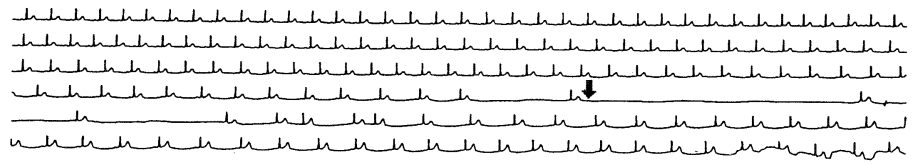

図 5 症例 2 の HUT 試験時の心拍数之血圧

11 時 07 分試験開始。

立位11分（11時18分）で心拍数，血圧の急激な低下を認める。（ホルター心電図は発作前後の約 3 分間を 記載した。りの位置で10秒間の心停止を認める。)

L。

ENG で明らかな眼振，異常眼球運動を認め ず。

ABR で異常を認めず。

心電図で異常を認めず。

血液検查で明らかな異常值なし。

頭部 CT を含む画像検査で異常を認めず。

Schellong Test : 陰性

安静時 : 心拍数 70 血圧 $135 / 80$

起立 1 分後 : 心拍数 68 血圧 $145 / 82$

起立 5 分後 : 心拍数 82 血圧 $145 / 80$

起立10分後：心拍数 85 血圧150/85（安静時間

10分, 単位 心拍数 $/ \mathrm{min}$, 血圧 $\mathrm{mmHg}$ )

HUT 試験：陽性（図 6 ）

立位直後に若干の血圧低下と心拍数の増加を認 めたが，めまいや眼前暗黒感はなかった。

30分の立位では, 血圧, 心拍数の明らかな低下 を認めなかったため，イソプロテレノール負荷し 再び立位とする。

立位 9 分でめまい時と類似の症状が出現した。

立位 9 分 30 秒でめまい感が増悪し, 血圧, 心拍 数も低下したため陽性と判断し, 試験を中止し

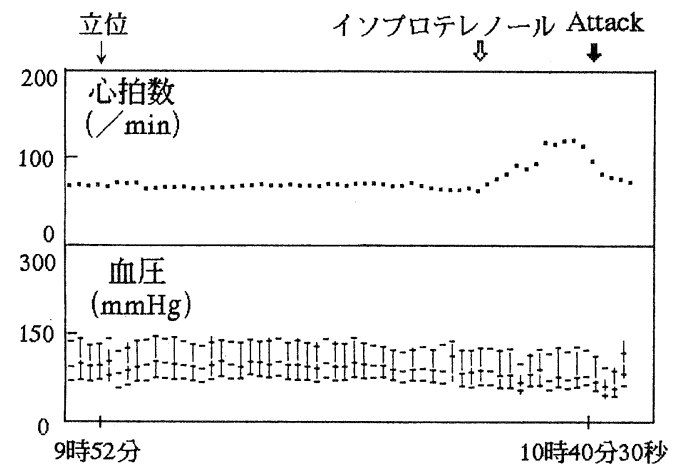

図 6 症例 3 の HUT 試験時の心拍数と血圧 9 時52分試験開始するが立位では陰性。 10時22分よりイソプロテレノール負荷（図 凤）し，再度立位とする。 立位 9 分 30 秒（10時 40 分 30 秒）で心拍数, 血圧の低下を認める。

た。

中止 30 秒後には心拍数, 血圧共に安静時と同様 の値に回復した。

治療と経過：この症例についてはイソプロテレ ノール負荷で発作が誘発され，年齢も60歳代であ 
ることを考え $\alpha_{1}$ 刺激薬で治療中である。今のと ころ大きな発作はなく経過良好である。

\section{考察}

VVR の存在は以前より知られていたが，1980 年代よりその検査法として HUT 試験が用いられ るようになり積極的に研究されるようになった。 HUT 試験は起立性低血圧, 自律神経失調症, 鬱 血性心不全などの評価法, 検査法として50年前か ら使用されてきた。近年欧米ではVVRの検査法 として盛んになってきており,ルーチンに施行し ている施設も少なくない(8)

VVRの機序については図 1 亿示した。立位ま たは座位では筋肉ポンプの作用も弱く, 下肢に血 液が貯留し, 心臓への静脈還流が減少する。この ため左室充満圧が低下して心拍出量も減少し血圧 低下を来す。これを補正するために左室の過剩収 縮が起き, 左室後壁に存在するメカノレセプター を介して C-fiber が刺激される。その結果, 迷走 神経の奇異性発火が起き, 瞬間的に循環量が低下 してめまい感, 眼前暗黒感, 失神発作等が起きる と考えられている。OD が交感神経活動不十分な ために起こることと比較すると, VVR は交感神 経の過剩反応のため迷走神経が過剩に反応すると 考光られる。以前は後遺症を残さない予後良好な めまいや失神発作と考光られてさたが99, VVR が原因と考光られる22歳の女性の死亡例なども報 告されるようになり突然死との関連が注目されて いる10)。VVRの主な症状としては, めまい感, 眼前暗黒感, 失神発作等が考兄られている。

今回の三症例はいずれも平衡機能検査及び循環 機能検査で明らかな異常所見が認められないにも かかわらず，自発性のめまいがあり，HUT 試験 で陽性所見を認めたことから原因を血管迷走神経 反射と考光た。血管迷走神経反射により血圧，心 拍数が急激に低下し, 椎骨脳底動脈領域をはじめ とする頭蓋内の血流低下によるめまい感が出現し たと考光られる。耳鳴の有無など自覚症状に若干 の差があるが，この原因については明確な証明は まだない。

治療法はまだ確立していないが，現在考えられ ている治療法を以下の $1 \sim 4$ 亿示した ${ }^{3) \sim 7) 。 ~}$

\section{1. $\beta$-ブロッカー (インデラル®) 内服}

迷走神経反射前の交感神経過剩反応 (心拍数増 加など）を抑制する。また，末梢の血管を収縮さ
せ，心臓への血流量を確保する。

2. ジソピラミド (リスモダン®) 内服

抗コリン作用により迷走神経反射を防止する。 心収縮力を低下させる。

末梢の血管を収縮させる。

3. $\alpha_{1}$ 刺激薬 (メトリジン $\left.\mathbb{R}\right)$ 内服

末梢の血管を収縮させ，心臓への血流量を確保 する。

4. ペースメーカーの使用

心抑制型では有効だが，末梢血管の拡張と，そ れに伴う血圧低下の予防は難しい。

現在, 我々は症例 1 のように安静時收縮期血圧 が $100 \mathrm{mmHg}$ 以上あり, 発作直前に急激な心拍 数の増加を認めた症例は $\beta$-ブロッカーで治療し, 症例 2 のように発作直前の心拍数に大きな変化が なく，血圧のみが低下するものにはジソピラミド を使用している。また， $\alpha_{1}$ 刺激薬については年 齢や発作の頻度，大きさを考慮して使用してい る。症例 3 のようにイソプロテレノール負荷で誘 発され，60歳以上の症例は $\alpha_{1}$ 刺激薬を使用する 場合が多い。薬剤の選定基準も含め, 治療基準, 治療期間, 効果の判定などについては今後も検討 が必要であると考劣ている。

次に, 現在一般的に外来で施行されている自律 神経の検査である Schellong test との比較を表 1 に示した。Wielingは Schellong testを含む standing up と HUT 試験では起立直後 (initial phase）の心拍数の変化に明らかな差異を認める と報告している。特に Schellong test では二峰性 の心拍変化が特徵的である ${ }^{11)} 12$ 。症例 1,2 で Schellong test が陰性であったことを考光ると， これらの違いが VVR 誘発に影響を与えている可 能性は高いと考光られる。しかし，VVR 誘発に 执いて Schellong test と HUT 試験を比較した報 告はないようである。これはVVRの性格上, Schellong test では安全面に問題があるためと考 えられる。今まで自律神経によるめまいはSchellong test から論じられることが多かった た1314)。確 かに Schellong testの方が自然な状態であり検査 も容易である。しかし, Schellong testでも VVR が誘発される可能性は否定できず，安全面には十 分な注意が必要と考兄る。また, HUT 試験につ いても短時間とはいえ心停止を伴うことが多く, 安全面には十分な注意が必要と考光る。実際, 
表 1 HUT 試験と Schellong Test (Standing Up) の比較 (Wieling ${ }^{11)}$ 上り改変)

\begin{tabular}{|c|c|c|}
\hline & $\begin{array}{l}\text { Head Up Tilt Test } \\
\text { (passive) }\end{array}$ & $\begin{array}{c}\text { Schellong Test } \\
\text { (active) }\end{array}$ \\
\hline 安静時間 & 15分 & 10１5分 \\
\hline 起立時間 & 30分 & 10分 \\
\hline 負荷 & イソプロテレノール負荷 & なし \\
\hline 血圧、心拍の測定 & 持続的に測定 & 数分おきに測定 \\
\hline $\begin{array}{l}\text { 起立直後（30秒間； } \\
\text { initial phase）の心拍 }\end{array}$ & 徐々に増加 & $\begin{array}{l}\text { 上昇 } \rightarrow \text { 低下 } \rightarrow \text { 上昇 } \\
\text { (2点のピークを認める) }\end{array}$ \\
\hline $\begin{array}{l}\text { 起立直後（30秒間； } \\
\text { initial phase） の血圧 }\end{array}$ & $\begin{array}{l}\text { やや低下した後 } \\
\text { ゆっくり上昇 }\end{array}$ & $\begin{array}{l}\text { 急激に低下した後 } \\
\text { 急激に上昇 }\end{array}$ \\
\hline 安全性 & $\begin{array}{c}\text { Tilt台に固定 } \\
\text { (失神を起こしても安全) }\end{array}$ & $\begin{array}{c}\text { 固定しておらず } \\
\text { やや危険 }\end{array}$ \\
\hline
\end{tabular}

表 2 各施設における HUT 試験のプロトコール, 感度, 特異度 (水牧3) より改变)

\begin{tabular}{|c|c|c|c|c|c|}
\hline 報告者（報告年） & $\begin{array}{c}\text { 症例数 } \\
(人)\end{array}$ & $\begin{array}{c}\text { Tilt 角度 } \\
\left({ }^{\bullet}\right)\end{array}$ & $\begin{array}{c}\text { 負荷時間 } \\
\text { (分) }\end{array}$ & 感 度 & 特異度 \\
\hline Abi-Sarma (1988) & 151 & 60 & 20 & $42 \%$ & $100 \%$ \\
\hline Strasberg(1989) & 40 & 60 & 60 & $38 \%$ & $100 \%$ \\
\hline Raviele (1990) & 30 & 60 & 60 & $50 \%$ & $100 \%$ \\
\hline Fitzpatrick (|و९|) & 71 & 60 & 60 & $75 \%$ & $93 \%$ \\
\hline Almquist (1989) & 15 & 80 & 10 & $\begin{array}{|cr|}\text { HUT } & 27 \% \\
\text { HUT +IP } & 82 \% \\
\end{array}$ & $\begin{array}{l}96 \% \\
88 \%\end{array}$ \\
\hline Waxman (1989) & 48 & 60 & 15 & \begin{tabular}{cr|} 
HUT & $0 \%$ \\
HUT + IP & $73 \%$ \\
\end{tabular} & $\begin{array}{l}96 \% \\
88 \%\end{array}$ \\
\hline Grubb (1991) & 25 & 80 & 30 & $\begin{array}{|cc|}\text { HUT } & 24 \% \\
\text { HUT + IP } & 60 \% \\
\end{array}$ & $\begin{array}{l}100 \% \\
100 \%\end{array}$ \\
\hline Sheldon(1992) & 85 & 80 & 10 & $\begin{array}{|cr|}\text { HUT } & 6 \% \\
\text { HUT + IP } & 78 \% \\
\end{array}$ & $100 \%$ \\
\hline Mizumaki & 55 & 60 & 20 & \begin{tabular}{cr|} 
HUT & $35 \%$ \\
HUT + IP & $78 \%$
\end{tabular} & $\begin{array}{l}94 \% \\
89 \%\end{array}$ \\
\hline
\end{tabular}

上段：Head-up tilt 単独角荷のみ、下段：Head-up tilt 単独鱼荷(HUT)とイソプロテ レノール鱼荷 tilt 併用 (HUT + IP)

HUT 試験後, 心臓マッサージによる蘇生が必要 であった症例も報告されて扮り8）試験の際はいか なる状沉にも対応できるようにスタッフ，機具共 に万全であることが望まれる。

発作に先行してめまい感が出現することも含 め, VVR はその機序も十分解明されているとは 言觉ず，それゆ光治療法もまだ確立してはいな い。また HUT 試験においても各施設に执いてプ ロトコールが異なって扮り，陽性率等にも差があ るのが現状である3)8)15)。(表 2)

今後, 病態, 検査法, 治療法など様々な面から
VVR に対する検討を重ねていきたいと考光る。 まとめ

1，めまいの三症例に HUT 試験を活用した。

2 , 各症例とも，主訴は立位または座位で起き る自発性のめまいであり, 症例 1,2 は失神の既 往があった。

3 , 症例 1,2 は立位 9 分 30 秒と 11 分で, 症例 3 はイソプロテレノール負荷 9 分 30 秒で失神, め まい感，血圧，及び心拍数の低下が出現し陽性と 診断された。

4 , 治療には $\beta$-ブロッカー, ジソピラミド, 
$\alpha_{1}$ 刺激薬を使用し経過は良好である。

5, HUT 試験はVVR の診断に有効であると 考えられた。

本稿を作製するにあたり，御指導いただき，さ らに御校閲賜わりました市川銀一郎教授に深甚な る謝意を表します。

また症例の検討にあたり御協力いただきました 当院循環器内科住吉正孝先生に深く感謝いたしま 寸。

\section{文 献}

1) Lewis T: Vasovagal syncope and the carotid sinus mechanisms. Br Med J 1: 873-876, 1932

2) 佐藤 廣, 飯沼宏之: 失神之 Tilting Test. 内科 74: 129-133, 1994

3 ) 水牧功一：失神一立位負荷試験の意義 : Current Topics in Cardiology 13: 22-32, 1995

4 ) 安部治彦: 神経調節性失神 (Neurally Mediated Syncope) の治療はどこまで行らべき か: 不整脈 News \& Views 1996. Spring 10: 9-14, 1995

5 ) Klingeneheben T, Kalusche D, Yi-Gang, et al: Changes in plasma epinephrine concentration and in heart rate during head up tilt testing in patients with neurocardiogenic syncope. J Cardiovasc Electrophysiol 7: 802 $-808,1996$

6 ) 別役徹生, 高野英行 : 神経調節性失神患者の ヘッドアップチルト試験中の血中カテュール アミン濃度の検討. 心藏 26 Suppl 4: 5457,1994
7 ) 住吉正孝 : 不整脈の新しい診断法と非薬物療 法 : 順天堂医 42: 450-458, 1997

8 ）栗田 明, 高瀬凡平 : Head-Up Tilt 試験. 呼吸之循環 43: 357-362, 1995

9 ) Kapoor MN: A prospective evaluation and follow-up of patient with syncope. N Engl J Med 309: 197-204, 1983

10）千代田和美, 小林洋一, 神保芳宏, 他: Vasovagal syncope 患者に拈恀急死例. 心 臓ペーシング 10: 288, 1994

11) Wieling W: Standing, orthostatic stress, and autonomic failure. in Autonomic failure: Bannister R. pp 308-320, Oxford University Press, Oxford, 1988

12）林 理之：体位変換試験, 起立試験とヘッド アップティルト試験. 日本自律神経学会 編. 自律神経機能検査第 2版. 4-8 頁, 文光 堂, 東京, 1995

13）野沢出, 中山久代, 橋本か拉り, 他: 若年 女性の立ちくらみ, めまいと低血圧との関連 について. 日耳鼻 98: 52-59, 1994

14）今井俊一, 野沢出, 今村まゆ久, 他 : めま い患者に括ける Schellong Test の再検討.

Equilibrium Res 54: 52-59, 1995

15) Janosik DK, Genovely H, Fredman C, et al: Discrepancy between head-up tilt test results utilizing different protocols in the same patient: Am Heart J 123: 538-541, 1992

$\left(\begin{array}{l}\text { 原稿到着 : 平成 } 9 \text { 年 } 8 \text { 月 } 27 \text { 日 } \\ \text { 別刷請求先 : 正木義男 } \\ \text { 干 } 113-0033 \text { 東京都文京区本郷2-1-1 } \\ \text { 順天堂大学医学部耳鼻咽喉科学教室 }\end{array}\right)$

